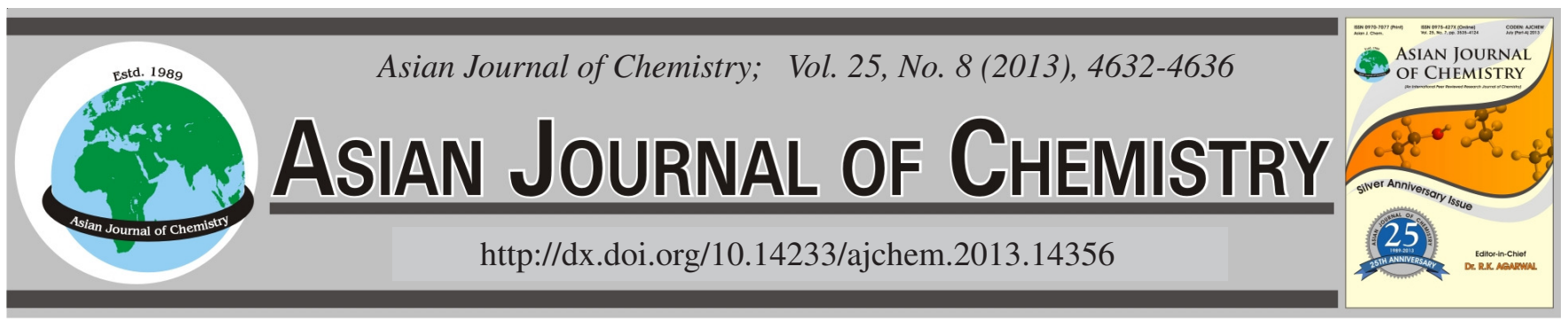

\title{
Synthesis of Dicationic Carbazole and 4'-Amino-(3,3'-bipyridine)-4-ol and the Spectral Characteristics of Carbazoles
}

\author{
K. WANG ${ }^{1}$, T. $\mathrm{LI}^{1,2}$, X.M. YE ${ }^{3}$, P. GUO ${ }^{2}$ and T. $\mathrm{JIA}^{2, *}$ \\ ${ }^{1}$ Hubei Key Lab of Novel Reactor \& Green Chemical Technology, Wuhan Institute of Technology, Wuhan, P.R. China \\ ${ }^{2}$ School of Pharmaceutical Sciences, Wuhan University, Wuhan, P.R. China \\ ${ }^{3}$ Wuhan Municipal Institute for Food and Drug Control, Wuhan, P.R. China \\ *Corresponding author: Fax :+ 8627 68759850; Tel: +86 27 68759947; E-mail: jiat@whu.edu.cn
}

(Received: 24 July 2012;

Accepted: 18 February 2013)

AJC-13029

The dicationic carbazole compound, 3,6-dimethyl-3,6-diazacarbazole diiodide (8) was prepared with 3-bromopyridine as a starting material |
by a six-step synthesis. The intermediates and target compound were confirmed by IR, NMR and MS. Meanwhile, UV-visible and |
fluorescent characteristics of 3,6-diazacarbazole (7) and 3,6-dimethyl-3,6-diazacarbazole diiodide (8) were investigated. It was found that
fluorescence decay over time of dicationic carbazole existed in low ionic strength and high ionic strength could stabilize the fluorescence
of dicationic carbazole.
Key Words: Dicationiccarbazole, Diazacarbazole, Catalytic hydrogenation, Fluorescence.

\section{INTRODUCTION}

The bio research of the derivatives of cationic carbazoles has drawn a lot of attention in recent years. According to the previous results, cationic carbazole has shown higher fluorescence intensity and larger two-photon excited fluorescence action cross-sections upon DNA binding ${ }^{1-5}$. And carbazoles can intercalate the DNA base pairs when DNA concentration is low while DNA groove binding will occur when DNA concentration increases ${ }^{4,5}$, which is suggestive that cationic carbazoles can be used as two-photon fluorescent probe for DNA and RNA. Meanwhile, cationic carbazoles are capable of stabilizing the telomere G-quadruplex and inhibiting the activity of telomerase, which supports these carbazoles to be potential antitumor drugs $s^{6,7}$.

These cationic carbazoles were derived from carbazole by linkage between pyridyl group and 3,6- or 2,7-position of carbazole and following alkylation of pyridyl group ${ }^{2-4}$. In 1980s, Kaczmarek had reported the synthetic route of 3,6diazacarbazole $^{8}$. It is an analog of carbazole, which $\mathrm{C}$ atoms at 3,6-position are replaced by $\mathrm{N}$ atoms and the alkylation of $\mathrm{N}$ at 3,6-position leads to the novel dicationic carbazole. However, this dicationic carbazole has not been investigated extensively in the recent 30 years.

The 3,6-dimethyl-3,6-diazacarbazole diiodide (8) was obtained by a six-step synthesis including $\mathrm{N}$-oxidation, nitration, Ullmann reaction, catalytic hydrogenation, cyclization and methylation. Especially, the reaction condition of catalytic hydrogenation by $\mathrm{Pd} / \mathrm{C}$ to prepare 4,4'-diamino-3,3'-bipyridine (5) was discussed. Moreover, the UV-visible and fluorescent characteristics of 3,6-diazacarbazole (7) and 3,6-dimethyl-3,6diazacarbazole diiodide $(\mathbf{8})$ were investigated.

\section{EXPERIMENTAL}

All reagents were used in analytical purity and without further treatment. Bruker AV400 (400 MHz) spectrometer; AB SCIEX API4000 LC/MS triple quad system for low resolution electrospray ionization (ESI) mass spectra; Agilent AccurateMass Q-TOF 6520 LC/MS and Thermo LTQ-Obitrap XL for high resolution electrospray ionization (ESI) mass spectra; Thermo Nexus 470 FT-IR; Beijing Pgeneral TU-1901UV-VIS spectrophotometer; Perkin-Elmer LS55 fluorescence spectrophotometer; VarioEL III elementary analyser; melting points were measured with a Beijing Tektronix X-4 apparatus (uncorrected).

3-Bromopyridine-N-oxide (1): 3-Bromopyridine (158 g, $1.00 \mathrm{~mol}$ ) was dissolved in $600 \mathrm{~mL}$ acetic acid. $160 \mathrm{~mL}$ of $30 \%$ of hydrogen peroxide solution was added to the above solution and stirred for $24 \mathrm{~h}$ at $80{ }^{\circ} \mathrm{C}$. Then the solution continued for $24 \mathrm{~h}$ after adding $120 \mathrm{~mL}$ of $30 \%$ of hydrogen peroxide solution again. After the reaction finished, unreacted 3-bromopyridine and acetic acid were distilled out and the residue oil was purified by vacuum distillation. Yield: $71 \mathrm{~g}$, yellow oil (1), $40.8 \%$. b.p. $140-142{ }^{\circ} \mathrm{C} / 3 \mathrm{mmHg} ; \mathrm{R}_{\mathrm{f}}=0.38$ 
$\left(\mathrm{CH}_{2} \mathrm{Cl}_{2}-\mathrm{MeOH} 20: 1\right) ;{ }^{1} \mathrm{H}$ NMR $\left(\mathrm{CDCl}_{3}\right) \delta: 7.23(\mathrm{dd}, J=7.9$, $\left.6.9 \mathrm{~Hz}, 1 \mathrm{H}, \mathrm{H}_{5}\right), 7.45\left(\mathrm{~d}, J=8.3 \mathrm{~Hz}, 1 \mathrm{H}, \mathrm{H}_{4}\right), 8.20(\mathrm{~d}, J=6.5$ $\left.\mathrm{Hz}, 1 \mathrm{H}, \mathrm{H}_{6}\right), 8.39$ (s, 1H, $\mathrm{H}_{2}$ ); IR ( $\mathrm{KBr}$, film, $\left.v_{\max }, \mathrm{cm}^{-1}\right)$ : 3098 , $1593(\mathrm{C}=\mathrm{C}, \mathrm{C}=\mathrm{N}), 1468,1424,1245(\mathrm{~N}-\mathrm{O}), 1014,891,667$ (C-Br); MS (ESI) m/z: 174, $176[\mathrm{M}+\mathrm{H}]^{+}$. The ${ }^{1} \mathrm{H}$ NMR data were similar to that in the reference?

3-Bromo-4-nitropyridine-N-oxide (2) and 5-bromo-2nitropyridine (3): 3-Bromopyridine-N-oxide (30 g, 0.172 $\mathrm{mol}$ ) and $48 \mathrm{~mL}$ of concentrated sulphuric acid were mixed in $0-5^{\circ} \mathrm{C}$, then the mixed acid of $48 \mathrm{~mL}$ of concentrated sulphuric acid and $72 \mathrm{~mL}$ of concentrated nitric acid was added dropwise. When the dropping was over, the solution was stirred at $90^{\circ} \mathrm{C}$ for $5 \mathrm{~h}$. Then the yellow reaction mixture was dumped into $200 \mathrm{~g}$ of crushed ice in mixing fully and adjusted the $\mathrm{pH}$ to 7 with aqueous ammonia solution, a large number of yellow needle-like solid was precipitated, filtered, washed using a small amount of ice water, dried and recrystallized by dichloromethane/petroleum ether to obtain yellow needle-like crystals, 3-bromo-4-nitropyridine-N-oxide (2); the mother liquor was for further distillation and the residue was treated by silica gel column chromatography with $\mathrm{CH}_{2} \mathrm{Cl}_{2}$ as an eluent. The first group was divided into 5-bromo-2-nitropyridine (3) and the second group was divided into 3-bromo-4-nitropyridineN-oxides (2).

3-Bromo-4-nitropyridine-N-oxides (2): Yield: $18.5 \mathrm{~g}$, $49.1 \%$. m.p. $159-160^{\circ} \mathrm{C}$ (reference value $\left.{ }^{10}: 152-153^{\circ} \mathrm{C}\right) ; \mathrm{R}_{\mathrm{f}}=$ $0.19\left(\mathrm{CH}_{2} \mathrm{Cl}_{2}\right)$; ${ }^{1} \mathrm{H}$ NMR $\left(\mathrm{CDCl}_{3}\right) \delta: 8.00(\mathrm{~d}, J=7.2 \mathrm{~Hz}, 1 \mathrm{H}$, $\left.\mathrm{H}_{5}\right), 8.16\left(\mathrm{~d}, J=7.2 \mathrm{~Hz}, 1 \mathrm{H}, \mathrm{H}_{6}\right), 8.48\left(\mathrm{~d}, J=1.9 \mathrm{~Hz}, 1 \mathrm{H}, \mathrm{H}_{2}\right)$; IR $\left(\mathrm{KBr}, \mathrm{v}_{\max }, \mathrm{cm}^{-1}\right): 3099,1588(\mathrm{C}=\mathrm{C}, \mathrm{C}=\mathrm{N}), 1551\left(\mathrm{NO}_{2}\right)$, 1501, $1339\left(\mathrm{NO}_{2}\right), 1294$ (N-O), 1254, 1050, 643 (C-Br); MS (APCI) $\mathrm{m} / \mathrm{z}: 219,221[\mathrm{M}+\mathrm{H}]^{+}$. The ${ }^{1} \mathrm{H}$ NMR data were similar to that in the reference ${ }^{10}$.

5-Bromo-2-nitropyridine (3): Yield: 2.0 g, $5.7 \%$. m.p. $160-162^{\circ} \mathrm{C}$ (reference value $\left.{ }^{11}: 149-151^{\circ} \mathrm{C}\right) ; \mathrm{R}_{\mathrm{f}}=0.88\left(\mathrm{CH}_{2} \mathrm{Cl}_{2}\right)$; ${ }^{1} \mathrm{H}$ NMR $\left(\mathrm{CDCl}_{3}\right) \delta: 8.20\left(\mathrm{~d}, J=1.2 \mathrm{~Hz}, 2 \mathrm{H}, \mathrm{H}_{2}, \mathrm{H}_{3}\right), 8.71-$ $8.72\left(\mathrm{~m}, 1 \mathrm{H}, \mathrm{H}_{6}\right) ;{ }^{13} \mathrm{C} \mathrm{NMR}(\mathrm{CDCl} 3) \delta: 119.38,127.10,142.44$, 150.15, 155.20; IR (KBr, $\left.v_{\max }, \mathrm{cm}^{-1}\right): 1635(\mathrm{C}=\mathrm{C}, \mathrm{C}=\mathrm{N}), 1529$ $\left(\mathrm{NO}_{2}\right), 1443,1376,1349\left(\mathrm{NO}_{2}\right), 1248,1086,1008,856,683$, 623 (C-Br); MS (ESI) m/z: 203, $205[\mathrm{M}+\mathrm{H}]^{+}$. The ${ }^{1} \mathrm{H}$ NMR, ${ }^{13} \mathrm{C}$ NMR and IR data were similar to that in the reference ${ }^{11,12}$.

4,4'-Dinitro-3,3'-bipyridine-N,N'-dioxide (4): 3-Bromo4-nitropyridine-N-oxide (18 g, $0.083 \mathrm{~mol})$ and $21.5 \mathrm{~g}$ copper powder were added to $90 \mathrm{~mL} \mathrm{DMF}$ and stirred for $5 \mathrm{~h}$ at $105^{\circ} \mathrm{C}$. After the reaction over, the reaction solution was filtered. The cake residue was washed with hot DMF $(90 \mathrm{~mL} \times 4 \mathrm{~mL}, 120$ $130{ }^{\circ} \mathrm{C}$ ) and combined the filtrate. It evaporated to $\mathrm{ca} .40 \mathrm{~mL}$ volume. Cooling to room temperature, it was dropped $c a$. $30 \mathrm{~mL}$ ammonia aqueous solution until it changed into green and a yellow precipitate appeared. Through filtration, dryness and recrystallization with DMF, 4,4 '-dinitro-3,3'-bipyridine$\mathrm{N}, \mathrm{N}$-dioxide (4) as yellow powder was obtained. Yield: 6.62 g, $57.3 \%$. m.p. $>300{ }^{\circ} \mathrm{C}$ (reference value ${ }^{8}>300{ }^{\circ} \mathrm{C}$ ); ${ }^{1} \mathrm{H} \mathrm{NMR}$ $\left(\mathrm{CF}_{3} \mathrm{COOD}\right) \delta: 8.46-8.48\left(\mathrm{~m}, 2 \mathrm{H}, \mathrm{H}_{3}, \mathrm{H}_{3^{\prime}}\right), 8.82-8.87(\mathrm{~m}, 4 \mathrm{H}$, $\left.\mathrm{H}_{2}, \mathrm{H}_{2}, \mathrm{H}_{6}, \mathrm{H}_{6}\right)$; IR $\left(\mathrm{KBr}, \nu_{\max }, \mathrm{cm}^{-1}\right): 3071,1603(\mathrm{C}=\mathrm{C}, \mathrm{C}=\mathrm{N})$, 1567, $1517\left(\mathrm{NO}_{2}\right), 1348\left(\mathrm{NO}_{2}\right), 1246(\mathrm{~N}-\mathrm{O})$; MS (ESI) m/z: $338\left[\mathrm{M}+\mathrm{CH}_{3} \mathrm{COOH}\right]^{+}$.

4,4'-Diamino-3,3'-bipyridine (5): 4,4'-Dinitro-3,3'bipyridine-N,N'-dioxide $(1.39 \mathrm{~g}, 0.0050 \mathrm{~mol})$ was added to
$42.5 \mathrm{~mL} 35 \%$ sulphuric acid and heated to $80{ }^{\circ} \mathrm{C}$. The zinc powder $(4.88 \mathrm{~g})$ was fractionated into the reaction solution. At the end of adding zinc, $20 \mathrm{~mL} 35 \%$ sulphuric acid was dropped into the solution and continued adding zinc powder $(4.88 \mathrm{~g})$ again. The mixture was stirred for $0.5 \mathrm{~h}$ and cooled to room temperature. With $50 \%$ sodium hydroxide solution to adjust the solution $\mathrm{pH}$ to 11 and evaporating the solvent, the residue was dried in vacuum and extracted successively with hot ethanol and hot isopropanol. Finally, the extracted liquids were combined and concentrated to dryness. 4,4'-diamino-3,3'bipyridine (5) was separated with neutral alumina column chromatography using $\mathrm{CH}_{2} \mathrm{Cl}_{2} / \mathrm{MeOH}$ (8:1, v:v) as an eluent. Yield: 0.44 g, $47.3 \%$. m.p. $289-291^{\circ} \mathrm{C}$ (reference value ${ }^{8}$ : 283$285^{\circ} \mathrm{C}$ ); $\mathrm{R}_{\mathrm{f}}=0.90$ (alumina plate, $\mathrm{CH}_{2} \mathrm{Cl}_{2}-\mathrm{MeOH} 10: 1$ ), 0.74 (silica gel plate, $\mathrm{CH}_{2} \mathrm{Cl}_{2}-\mathrm{MeOH}-\mathrm{NH}_{3} \cdot \mathrm{H}_{2} \mathrm{O} 30: 10: 1$ ); ${ }^{1} \mathrm{H}$ NMR $\left(\mathrm{DMSO}-d_{6}\right) \delta: 5.54\left(2 \mathrm{H}, \mathrm{NH}_{2}\right), 5.56\left(2 \mathrm{H}, \mathrm{NH}_{2}\right), 6.65(\mathrm{~d}, J=$ $\left.5.6 \mathrm{~Hz}, 2 \mathrm{H}, \mathrm{H}_{5}, \mathrm{H}_{5^{\prime}}\right), 7.87$ (s, 2H, $\left.\mathrm{H}_{2}, \mathrm{H}_{2^{\prime}}\right), 8.03$ (d, J = 5.6 Hz, $\left.2 \mathrm{H}, \mathrm{H}_{6}, \mathrm{H}_{6}\right)$; IR $\left(\mathrm{KBr}, v_{\max }, \mathrm{cm}^{-1}\right)$ : $3428\left(\mathrm{NH}_{2}\right), 3087,1642$, $1583(\mathrm{C}=\mathrm{C}, \mathrm{C}=\mathrm{N}), 1496,1414,995,824 ; \mathrm{HRMS}(\mathrm{ESI}) \mathrm{m} / \mathrm{z}$ : calcd. for $\mathrm{C}_{10} \mathrm{H}_{11} \mathrm{~N}_{4}[\mathrm{M}+\mathrm{H}]^{+}$187.0984, found 187.0980.

4'-Amino-(3,3'-bipyridine)-4-ol (6): 4,4'-Dinitro-3,3'bipyridine-N,N'-dioxide and the catalyst $(10 \% \mathrm{Pd} / \mathrm{C}$ or Raney $\mathrm{Ni}$ ) were added to the ethanol. A suspension was heated to 50 ${ }^{\circ} \mathrm{C}$ and accessed hydrogen with TLC monitoring the reaction progress. After the reaction end, the mixture was filtered and the filtrate was concentrated into dryness. The residue was purified by silica gel column chromatography, using $\mathrm{CH}_{2} \mathrm{Cl}_{2}$ / $\mathrm{MeOH} / \mathrm{NH}_{3} \cdot \mathrm{H}_{2} \mathrm{O}(30: 10: 1, \mathrm{v} / \mathrm{v} / \mathrm{v})$ as an eluent. The first group was 4,4'-diamino-3,3'-bipyridine (5) and the second group was 4'-amino-(3,3'-bipyridine)-4-ol (6). Yield was not calculated in virtue of investigating the solvent and catalyst quantity for the catalytic hydrogenation research by ${ }^{1} \mathrm{H}$ NMR. m.p. 296$298^{\circ} \mathrm{C}$ (reference value ${ }^{12}: 290{ }^{\circ} \mathrm{C}$ ); $\mathrm{R}_{\mathrm{f}}=0.39$ (silica gel plate, $\left.\mathrm{CH}_{2} \mathrm{Cl}_{2}-\mathrm{MeOH}-\mathrm{NH}_{3} \cdot \mathrm{H}_{2} \mathrm{O}, 30: 10: 1, \mathrm{v} / \mathrm{v} / \mathrm{v}\right) ;{ }^{1} \mathrm{H}$ NMR (DMSO- $d_{6}$ ) $\delta: 5.73\left(\mathrm{br}, 2 \mathrm{H}, \mathrm{NH}_{2}\right), 6.29\left(\mathrm{~d}, J=7.1 \mathrm{~Hz}, 1 \mathrm{H}, \mathrm{H}_{5}\right), 6.63(\mathrm{~d}, J=$ $\left.5.6 \mathrm{~Hz}, 1 \mathrm{H}, \mathrm{H}_{5^{\prime}}\right), 7.75\left(\mathrm{dd}, J=7.2,1.6 \mathrm{~Hz}, 1 \mathrm{H}, \mathrm{H}_{6}\right), 7.80(\mathrm{~d}, J=$ $\left.1.6 \mathrm{~Hz}, 1 \mathrm{H}, \mathrm{H}_{2}\right), 7.96\left(\mathrm{~s}, 1 \mathrm{H}, \mathrm{H}_{2^{\prime}}\right), 8.01\left(\mathrm{~d}, J=5.6 \mathrm{~Hz}, 1 \mathrm{H}, \mathrm{H}_{6}\right)$; IR $\left(\mathrm{KBr}, \mathrm{v}_{\max }, \mathrm{cm}^{-1}\right): 3323(\mathrm{OH}), 3228\left(\mathrm{NH}_{2}\right), 3088,1633$, $1592(\mathrm{C}=\mathrm{C}, \mathrm{C}=\mathrm{N}), 1516,1384,1188,997,830$; HRMS (ESI) $\mathrm{m} / \mathrm{z}$ : calcd. for $\mathrm{C}_{10} \mathrm{H}_{10} \mathrm{~N}_{3} \mathrm{O}[\mathrm{M}+\mathrm{H}]^{+}$188.0824, found 188.0825.

3,6-Diazacarbazole (7): 4,4'-Diamino-3,3'-bipyridine (1.80 g and $0.0097 \mathrm{~mol}$ ) and $27.5 \mathrm{~g}$ anhydrous $\mathrm{ZnCl}_{2}$ were mixed into round-bottomed flask and heated to $350-375{ }^{\circ} \mathrm{C}$ for $4 \mathrm{~h}$. Afted cooled to room temperature, $65 \mathrm{~mL}$ water was added to the reaction mixture forming a light black solution and then $50 \%$ sodium hydroxide solution was used for alkalization, gray solid precipitated, filtered and extracted with hot ethanol $(50 \mathrm{~mL} \times 5 \mathrm{~mL})$. Collected ethanol solution was concentrated into dryness and the residue was purified by silica gel column chromatography using $\mathrm{CH}_{2} \mathrm{Cl}_{2} / \mathrm{MeOH}$ (10:1, v:v) as an eluent to get 3,6-diazacarbazole (7). Yield: $1.08 \mathrm{~g}, 65.8 \%$. m.p. $>300{ }^{\circ} \mathrm{C}$ (reference value ${ }^{8}>300{ }^{\circ} \mathrm{C}$ ); $\mathrm{R}_{\mathrm{f}}=0.18\left(\mathrm{CH}_{2} \mathrm{Cl}_{2^{-}}\right.$ MeOH 10:1); ${ }^{1} \mathrm{H}$ NMR (DMSO- $\left.d_{6}\right) \delta: 7.58(\mathrm{~d}, J=5.7 \mathrm{~Hz}, 2 \mathrm{H}$, $\left.\mathrm{H}_{1}, \mathrm{H}_{8}\right), 8.52\left(\mathrm{~d}, J=5.7 \mathrm{~Hz}, 2 \mathrm{H}, \mathrm{H}_{2}, \mathrm{H}_{7}\right), 9.46$ (s, 2H, $\left.\mathrm{H}_{4}, \mathrm{H}_{5}\right)$, 12.18 (br, $\left.1 \mathrm{H}, \mathrm{H}_{9}\right)$; IR (KBr, $\left.\mathrm{v}_{\max }, \mathrm{cm}^{-1}\right)$ : 2921, $2670(\mathrm{~N}-\mathrm{H})$, 1627, 1577 (C=C, C=N), 1470, 1384, 1204, 803, 663; HRMS (ESI) $\mathrm{m} / \mathrm{z}$ : calcd. for $\mathrm{C}_{10} \mathrm{H}_{8} \mathrm{~N}_{3}[\mathrm{M}+\mathrm{H}]^{+} 170.0718$, found 170.0706 . 
3,6-Dimethyl-3,6-diazacarbazole diiodide (8): To the solution of 3,6-diazacarbazole (100 mg, $0.59 \mathrm{mmol})$ dissolved in $30 \mathrm{~mL}$ methanol, $10 \mathrm{~mL} \mathrm{CH}_{3} \mathrm{I}$ was added and refluxed for $24 \mathrm{~h}$ to get a yellow precipitate. The precipitation was filtered and dried to obtain 3,6-dimethyl-3,6-diazacarbazole diiodide (8). Yield: $150 \mathrm{mg}, 56.1 \%$. m.p. $267-269^{\circ} \mathrm{C} ;{ }^{1} \mathrm{H}$ NMR (DMSO$\left.d_{6}\right) \delta: 4.52\left(\mathrm{~s}, 6 \mathrm{H}, \mathrm{CH}_{3}\right), 8.41\left(\mathrm{~d}, J=7.0 \mathrm{~Hz}, 2 \mathrm{H}, \mathrm{H}_{1}, \mathrm{H}_{8}\right), 9.02$ (d, $\left.J=7.0 \mathrm{~Hz}, 2 \mathrm{H}, \mathrm{H}_{2}, \mathrm{H}_{7}\right), 10.03\left(\mathrm{~s}, 2 \mathrm{H}, \mathrm{H}_{4}, \mathrm{H}_{5}\right)$; IR ( $\mathrm{KBr}$, $\left.V_{\max }, \mathrm{cm}^{-1}\right): 2936,2786,2637(\mathrm{~N}-\mathrm{H}), 1630,1593(\mathrm{C}=\mathrm{C}, \mathrm{C}=\mathrm{N})$, 1472, 1271, 1246, 1183, 830; MS (ESI) m/z: 452 [M-H] $]^{-}$; Anal. calcd. (\%) for $\mathrm{C}_{12} \mathrm{H}_{13} \mathrm{I}_{2} \mathrm{~N}_{3}$ : C 31.81, H 2.89, N 9.27; found (\%) C 31.90, H 2.90, N 9.29.

UV Spectrum: 3,6-Diazacarbazole (7) EtOH solution (2 $\times 10^{-5} \mathrm{~mol} / \mathrm{L}$ ) and 3,6-dimethyl-3,6-diazacarbazole diiodide (8) aqueous solution $\left(2 \times 10^{-5} \mathrm{~mol} / \mathrm{L}\right)$ were tested by UV-visible spectroscopy. The length of the cells was $1 \mathrm{~cm}$ and the spectroscopy was investigated at $20^{\circ} \mathrm{C}$ and under 1 atm pressure.

Fluorescent spectrum: 3,6-Diazacarbazole (7) $\mathrm{EtOH}$ solution $\left(1 \times 10^{-7} \mathrm{~mol} / \mathrm{L}\right)$ and 3,6-dimethyl-3,6-diazacarbazole diiodide $(\mathbf{8})$ aqueous solution $\left(1 \times 10^{-7} \mathrm{~mol} / \mathrm{L}\right)$ were tested by FL spectroscopy. Excitation and emission slits was $10 \mathrm{~nm}, 5$ $\mathrm{nm}$, respectively. Scanning speed was $500 \mathrm{~nm} / \mathrm{min}$. The length of the cells was $1 \mathrm{~cm}$ and the spectroscopy was investigated at $20{ }^{\circ} \mathrm{C}$ and under 1 atm pressure. Fluorescence decay was performed at a freshly diluted dicationic carbazole $(0.1 \mu \mathrm{M})$ in four aqueous solutions of various ionic strengths, which were adjusted with $\mathrm{NaCl}$. The relative fluorescence intensity changes of maximum emissions over time were recorded at $\mathrm{Ex} / \mathrm{Em}$ slit $10 \mathrm{~nm} / 10 \mathrm{~nm}$, and the fluorescence excitation and emission spectra were also recorded until little fluorescence decay occurred.

\section{RESULTS AND DISCUSSION}

Synthetic research: The preparation of compound 4, 5 and 3,6-diazacarbazole (7) were reported by Kaczmarek with 3-bromo-4-nitropyridine $\mathrm{N}$-oxide (2) as a starting material ${ }^{8}$. Thus 3-bromopyridine was used as a starting material to accomplish the synthesis. The route was shown in Scheme-I.

In the preparation of compound $\mathbf{1}$, the yield was not improved by extending the reaction time and increasing the quantity of $\mathrm{H}_{2} \mathrm{O}_{2}$. As for compound 2, the post-treatment was very important that ammonia water was used for $\mathrm{pH}$ adjusting instead of $\mathrm{NaOH}^{9}$, which reason is that the solubility of $\left(\mathrm{NH}_{4}\right)_{2} \mathrm{SO}_{4}$ in water is 4 times as much as that of $\mathrm{Na}_{2} \mathrm{SO}_{4}$ and an ample amount of salt deposits can be avoided. A byproduct was obtained as well and it was confirmed to be 5-bromo-2nitropyridine (3), which was usually prepared by oxidation of 5-bromo-2-aminopyridine ${ }^{10}$. So this method of synthesizing compound $\mathbf{3}$ was reported firstly in this paper.

In the Ullmann reaction of preparing $^{8}$ compound 4 , the ammonia water should not be replaced by other base due to its chelating with $\mathrm{Cu}^{2+}$, which was produced in Ullmann reaction and chelated with compound $\mathbf{4}$. The reduction of compound 4 was complicated involving two nitro- and two $\mathrm{N}$-oxidation pyridines. The reported zinc powder reduction has low yield and inconvenient treatment ${ }^{8}$. Catalytic hydrogenation of one nitro- and one pyridine $\mathrm{N}$-oxide by $\mathrm{Pd} / \mathrm{C}$ or Raney nickel was reported, which is high-yield and operationconvenient ${ }^{13-15}$. However, in catalytic hydrogenation of compound 4, not only 4,4'-diamino-3,3'-bipyridine (5) was obtained as the target product, but also $4^{\prime}$-amino-(3,3'bipyridine)-4-ol (6) was obtained as the side product.

The cyclization of compound $\mathbf{5}$ above melting point of $\mathrm{ZnCl}_{2}$ afforded 3,6-diazacarbazole (7). Methylation of compound 7 by an excess amount of methyl iodide afforded dicationic carbazole (8) and inhibited the generation of the mono-methylated product. The central $\mathrm{N}$ atom would not involve in reaction due to the conjugative effect of planar aromatic condensed ring.

The mixture of $\mathbf{5}$ and $\mathbf{6}$ were obtained by catalytic hydrogenation with $\mathrm{Pd} / \mathrm{C}$ or Raney nickel as catalyst. The total yield was quantitative nearly and the post-treatment was convenient. Two reaction factors of catalyst quantity and existence of $\mathrm{H}_{2} \mathrm{O}$ in $\mathrm{EtOH}$ were tested in $\mathrm{Pd} / \mathrm{C}$ catalytic hydrogenation system. The result is shown in Table- 1 . With the increasing of the catalyst from 50-100 mg, the ratio of compound 5/6 leads to $2: 1$, which suggests that the catalyst quantity is crucial to the yield of compound 5. Additionally, the existence of $\mathrm{H}_{2} \mathrm{O}$ would be helpful to increase the yield of compound $\mathbf{6}$, which suggests that a nucleophilic attack of water molecule occur during the reduction of the nitro group on the intermediate ${ }^{12}$.

In addition, ${ }^{1} \mathrm{H}$ NMR spectra of 4,4'-diamino-3, $3^{\prime}$ bipyridine (5) and 4'-amino-(3,3'-bipyridine)-4-ol (6) were worth to be studied, as shown in Figs. 1 and 2, respectively. Figs. 1 and 3 showed that $\mathrm{H}$ of two amino group appear at $5.55 \mathrm{ppm}$ (but they will disappear when $\mathrm{D}_{2} \mathrm{O}$ exchanged) and have double peaks because of forming hydrogen bond between $\mathrm{H}$ of amino group and $\mathrm{N}$ of adjacent amino group, which leads to different chemical shifts of $\mathrm{H}$ of two amino group. While, in Figs. 2 and 3, H of phenolic hydroxyl group in compound 6 was easy to separate due to the electron withdrawing effect from the pyridine group, which made the electron density of oxygen anion higher and easier to form hydrogen bond with neighboring amino. So $\mathrm{H}$ of amino group shifted to $5.73 \mathrm{ppm}$ toward
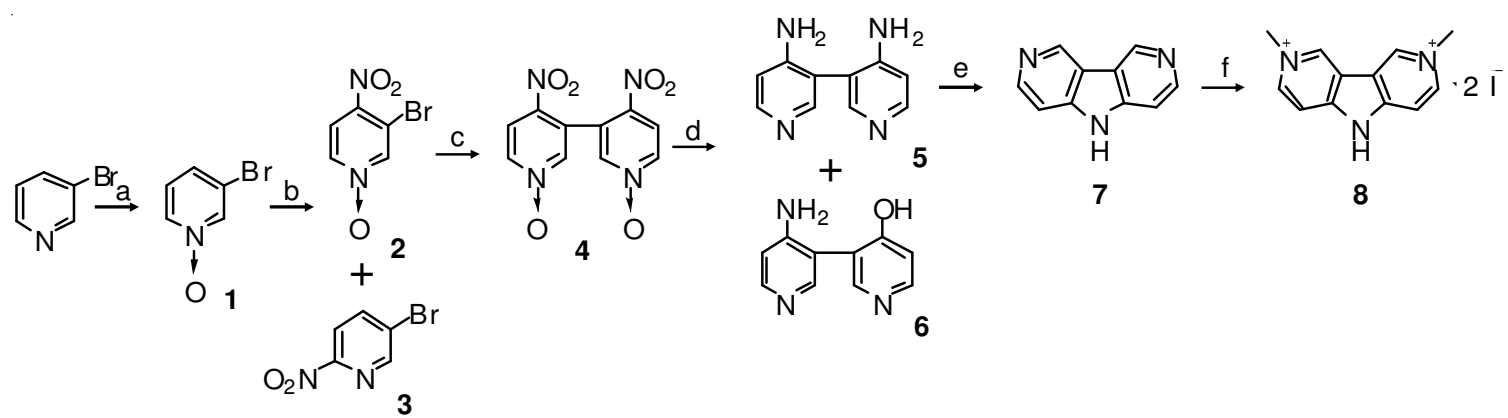

Scheme-I: Reagents and conditions: (a) $\mathrm{H}_{2} \mathrm{O}_{2}, \mathrm{CH}_{3} \mathrm{COOH}$. (b) $\mathrm{H}_{2} \mathrm{SO}_{4}, \mathrm{HNO}_{3}$. (c) $\mathrm{Cu}$, DMF. (d) $\mathrm{Pd} / \mathrm{C}, \mathrm{H}_{2}, \mathrm{EtOH}$. (e) $\mathrm{ZnCl}_{2}$. (f) $\mathrm{CH}_{3} \mathrm{I}, \mathrm{CH}_{3} \mathrm{OH}$ 


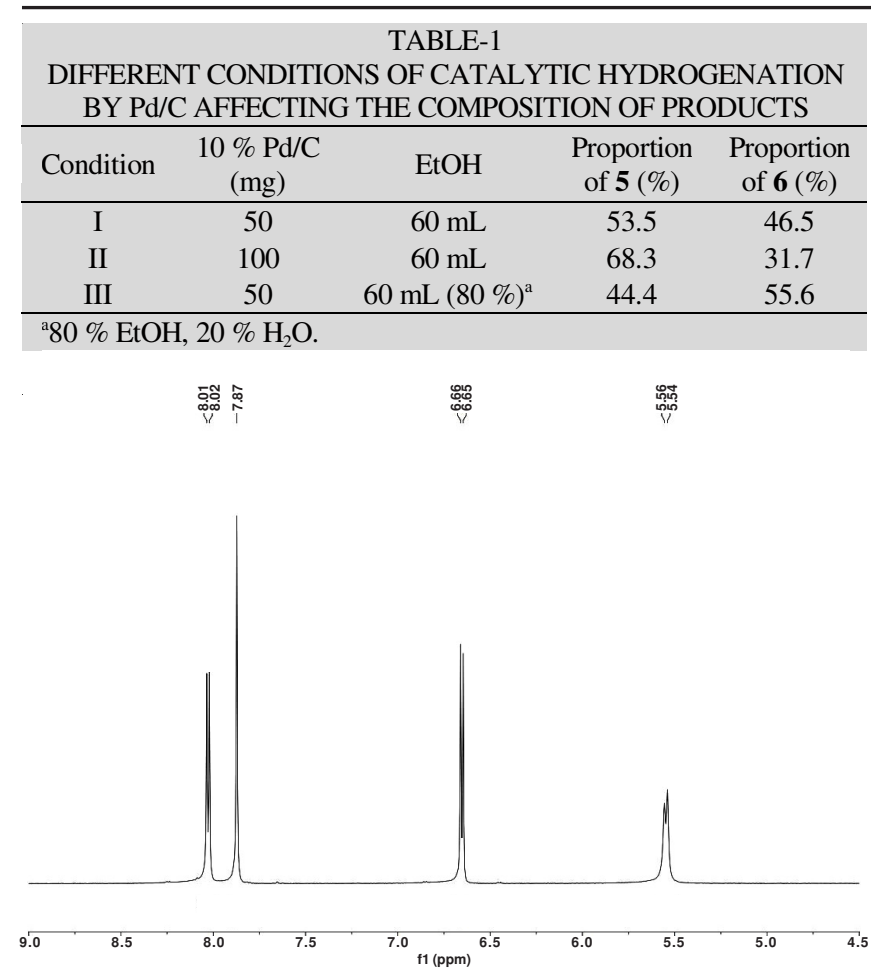

Fig. 1. ${ }^{1} \mathrm{H}$ NMR of 4,4'-diamino-3,3'-bipyridine (5)

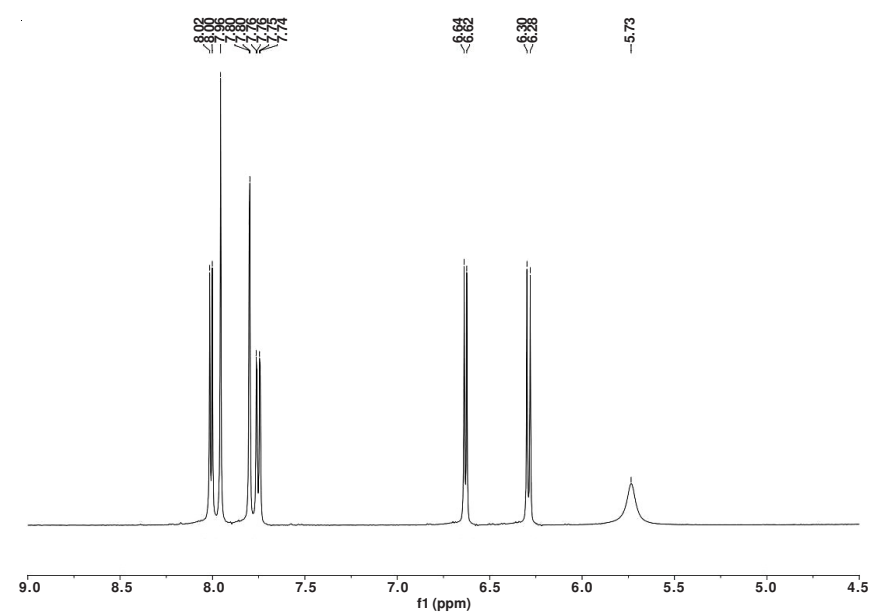

Fig. 2. ${ }^{1} \mathrm{H}$ NMR of 4'-amino-(3,3'-bipyridine)-4-ol (6)
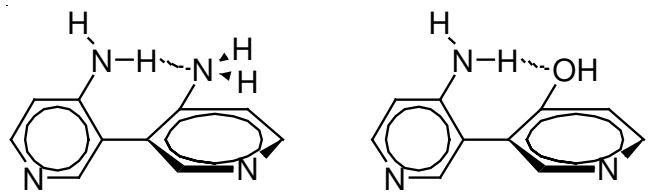

Fig. 3. Hydroge bond between compound 5 (left) and $\mathbf{6}$ (right)

the low field with shielding effect and displayed a broad peak. Simultaneously, $\mathrm{H}$ chemical shift value of pyridine containing $\mathrm{OH}$ changed and emerged coupling effect of $\mathrm{H}_{2}(7.80 \mathrm{ppm})$ and $\mathrm{H}_{6}(7.75 \mathrm{ppm})$.

UV and fluorescent characteristics: In the UV-visible spectrum, compound 7 showed only a $230 \mathrm{~nm}$ peak. When methylation of compound $\mathbf{7}$ was to form compound $\mathbf{8}$, the absorption peak of $\mathbf{8}$ changed into 226, 270 and $333 \mathrm{~nm}$. The UV data were showed in Fig. 4 and Table-2.

As shown in Fig. 5 and Table-2, the maximum peak of excitation $\left(\lambda_{\mathrm{ex}}\right)$ and emission $\left(\boldsymbol{\lambda}_{\mathrm{em}}\right)$ spectra of compound 7

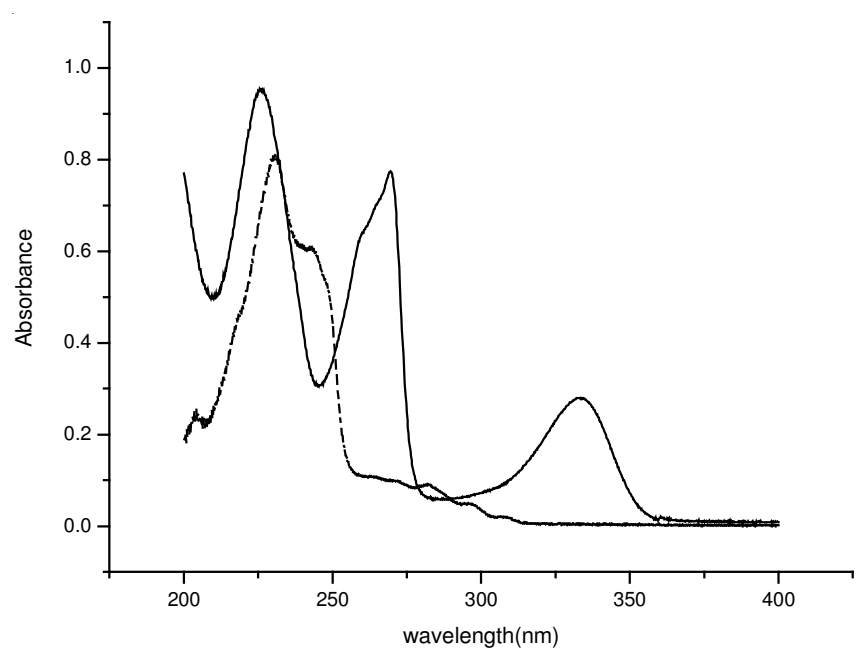

Fig. 4. UV-visible spectra of compound $\mathbf{7}$ (dash line) and $\mathbf{8}$ (solid line)

TABLE-2

DATA OF UV-VIS AND FLUORESCENCE SPECTRA

\begin{tabular}{cccc}
\hline \multirow{2}{*}{ Compound } & \multirow{2}{*}{ UV-VIS $(\mathrm{nm})$} & \multicolumn{2}{c}{ Fluorescence } \\
\cline { 3 - 4 } & & Excitation $(\mathrm{nm})$ & Emission $(\mathrm{nm})$ \\
\hline $\mathbf{7}$ & 230 & 224 & 342 \\
$\mathbf{8}$ & $226,270,333$ & $222,266,332$ & 388 \\
\hline
\end{tabular}

appeared at 224 and $342 \mathrm{~nm}$. The $\lambda_{\mathrm{ex}}$ of compound $\mathbf{8}$ has three peaks including 222, 266 and $332 \mathrm{~nm}$. But $\lambda_{\mathrm{em}}$ of $\mathbf{8}$ showed at $388 \mathrm{~nm}$. Seen from the fluorescence spectra of compounds 7 and $\mathbf{8}$, fluorescence excitation and fluorescence emission peak values of compound $\mathbf{8}$ showed $42 \mathrm{~nm}$ and $45 \mathrm{~nm}$ red shift compared with that of compound 7. It suggests that there would be existence of self accumulation of compound 7 and intermolecular exclusive effect of compound $\mathbf{8}$ with positive charge structure.

Additionally, the fluorescence decay of compound $\mathbf{8}$ over time in aqueous solution of low ionic strength was observed. It was found that the rate of decay was negatively correlated with ionic strength, which was adjusted with $\mathrm{NaCl}$. The relative fluorescence intensity changes of maximum emissions over time were summarized in Fig. 6(left). The fluorescence excitation and emission spectra of compoud $8(0.1 \mu \mathrm{M})$ in four aqueous solutions of various ionic strengths were shown in Fig. 6(right), which were measured after $72 \mathrm{~h}$.

With decreasing ionic strength, fluorescence intensity of the excitation and emission spectra of compound $\mathbf{8}$ decayed. Fluorescence decay over time of compound $\mathbf{8}$ existed in low ionic strength, but high ionic strength could stabilize the fluorescence. It suggests that there would be self-aggregate of dicationic carbazole $\mathbf{8}$ in low ionic strength ${ }^{16}$.

\section{Conclusion}

With an accessible starting material of 3-bromopyridine, 3,6-dimethyl-3,6-diazacarbazole diiodide (8) was prepared and the synthetic routine was improved. 5-Bromo-2-nitropyridine (3) was obtained as byproduct in nitration reaction of compound 1. 4,4'-Diamino-3,3'-bipyridine (5) and 4'-amino-(3,3'bipyridine)-4-ol (6) was obtained through catalytic hydrogenation of compound $\mathbf{4}$ and two reaction factors of catalyst quantity and existence of $\mathrm{H}_{2} \mathrm{O}$ in EtOH affected the composition of products, in which catalyst quantity is crucial to the 

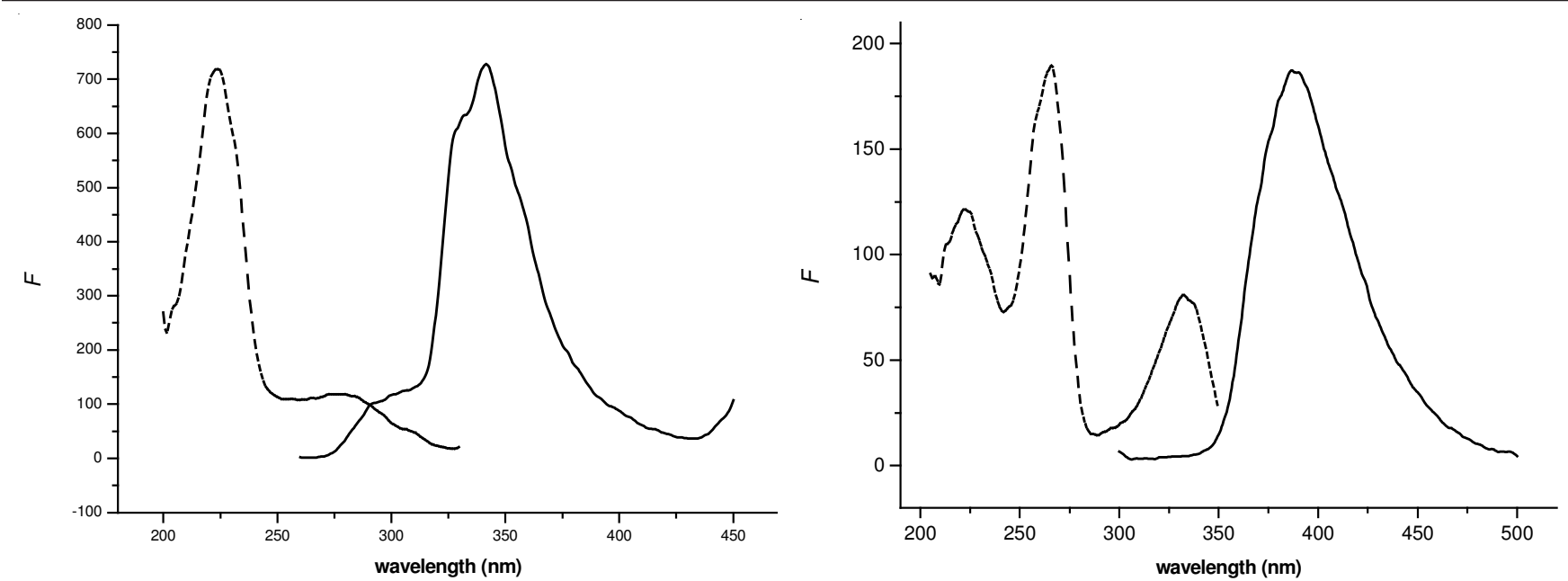

Fig. 5. Fluorescence excitation and emission spectra of compound $\mathbf{7}$ (left) and $\mathbf{8}$ (right) (dash line represented the excitation, solid line represented the emission)
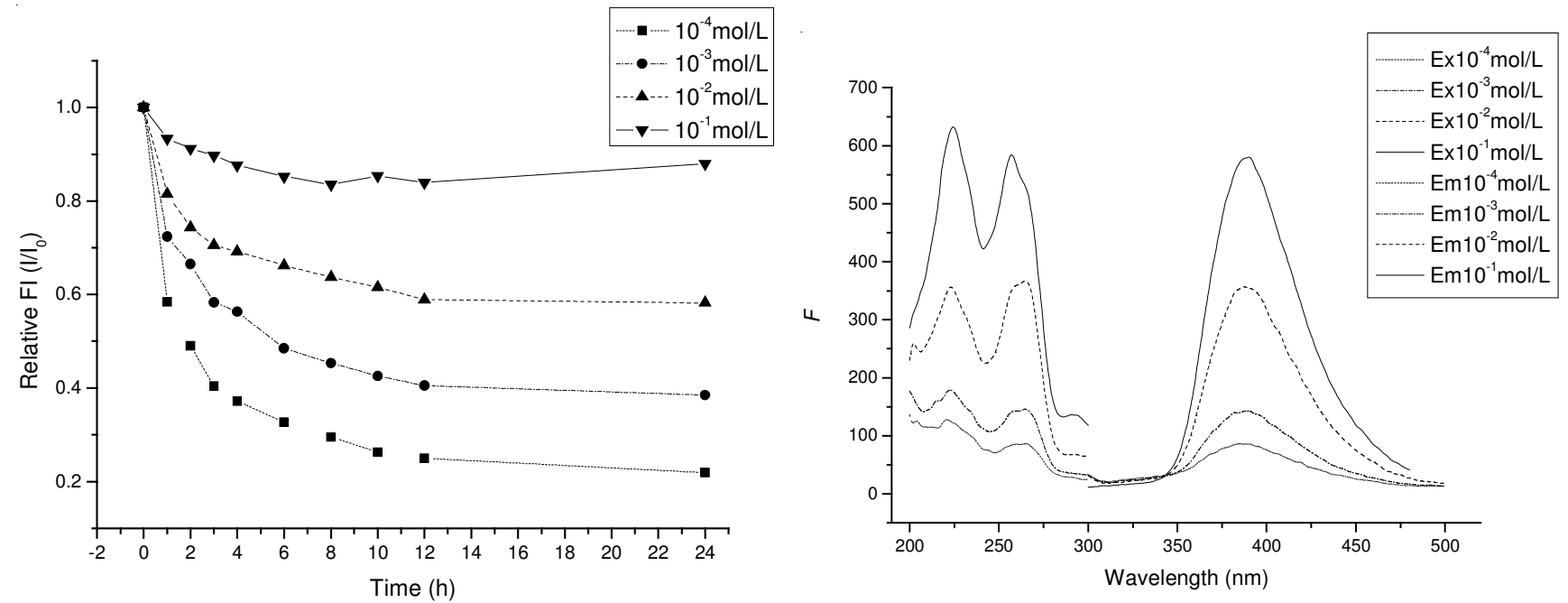

Fig. 6. Relative fluorescence intensity of compound $\mathbf{8}$ changes over tome (left). [compound 8] $=1.0 \times 10^{-7} \mathrm{M}$. 1: $1.0 \times 10^{-4} \mathrm{M} \mathrm{NaCl} ; 2: 1.0 \times 10^{-3} \mathrm{M} \mathrm{NaCl}$; 3: $1.0 \times 10^{-2} \mathrm{M} \mathrm{NaCl}$; 4: $0.1 \mathrm{M} \mathrm{NaCl}$. b: Fluorescence excitation and emission spectra of dicationic carbazole in four aqueous solutions (right). [Compound 8] $=1.0 \times 10^{-7} \mathrm{M}$

yield of compound $\mathbf{5}$. The UV-visible and fluorescence of $\mathbf{7}$ and $\mathbf{8}$ were evaluated and fluorescence decay over time of dicationic carbazole $\mathbf{8}$ was found in low ionic strength. As for their bioactivity, DNA interaction, DNA cleavage and cellular cytotoxicity are under way.

\section{ACKNOWLEDGEMENTS}

The authors acknowleged the financial support from the National Natural Science Foundation of China (No. 21002074, 20902071).

\section{REFERENCES}

1. X. Liu, Y.M. Sun, Y.H. Zhang, F. Miao, G.C. Wang, H.S. Zhao, X.Q. Yu, H. Liu and W.Y. Wong, Org. Biomol. Chem., 9, 3615 (2011).

2. X.J. Feng, P.L. Wu, F. Bolze, H.W.C. Leung, K.F. Li, N.K. Mak, D.W.J. Kwong, J.-F. Nicoud, K.W. Cheah and M.S. Wong, Org. Lett., 12, 2194 (2010).

3. X. Liu, Y.M. Sun, Y.H. Zhang, N. Zhao, G.C. Wang, H.S. Zhao, X.Q. Yu and H. Liu, J. Fluoresc., 21, 497 (2011).

4. Y.H. Zhang, Y.M. Sun, X. Liu, N. Zhao, X.Q. Yu and B.B. Huang, Chem. J. Chin. Univ., 31, 1860 (2010) (in Chinese).
5. P.F. Jia, H. Liu, Y.H. Zhang, X. Liu, N. Zhao and X.Q Yu, Chem. J. Chin. Univ., 31, 1075 (2010) (in Chinese).

6. X.F. Zhang, H.J. Zhang, J.F Xiang, Q. Li, Q.F. Yang, Q. Shang, Y.X. Zhang and Y.L. Tang, J. Mol. Struct., 982, 133 (2010).

7. F.C. Huang, C.C. Chang, P. J. Lou, I.C. Kuo, C.W. Chien, C.T. Chen, F.Y. Shieh, T.C. Chang and J.J. Lin, Mol. Cancer Res., 6, 955 (2008).

8. L. Kaczmarek, A. Becalski and P. Nantka-Namirski, Polish J. Chem., 54, 1585 (1980).

9. D. Rong, A.V. Philips, S.R. Rubio, M.A. Castro and R.T. Wheelhouse, Tetrahedron Lett., 49, 6933 (2008).

10. R.W. Daisley and R.J. Hanbali, Opp. Briefs., 15, 280 (1983).

11. S.J. Nara, M. Jha, J. Brinkhorst, T.J. Zemanek and D.A. Pratt, J. Org. Chem., 73, 9326 (2008).

12. A. Becalski, L. Kaczmarek and P. Nantka-Namirski, Bull. Polish Acad. Sci. Chem., 32, 105 (1984).

13. Y. Oguro, N. Miyamoto, T. Takagi, K. Okada, Y. Awazu, H. Miki, A. Hori, K. Kamiyama and S. Imamura, Bioorg. Med. Chem., 18, 7150 (2010).

14. P. Kavanagh and D. Leech, Tetrahedron Lett., 45, 121 (2004).

15. M.C. Liu, M.Z. Luo, D.E. Mozdziesz, T.S. Li, G.E. Dutschman, E. Gyllen, Y.C. Cheng and A.C. Sartorelli, Nucleosides Nucleotrides Nucleic Acids, 20, 1975 (2001).

16. A. Bañares-Hidalgo, A. Bolaños-Gutiérrez, F. Gil, E.J. Cabré, J. PérezGil and P. Estrada, J. Ind. Microbiol. Biotechnol., 35, 1367 (2008). 